\title{
Prevention of cognitive deficits in Alzheimer's mouse model by elevating brain magnesium
}

\author{
Guosong Liu \\ From 2011 International Conference on Molecular Neurodegeneration \\ Shanghai, China. 22-24 September 2011
}

Memory functions decline with age, and severely deteriorate during Alzheimer's disease (AD). Several studies suggest that dietary/environmental factors can reduce the prevalence of $\mathrm{AD}$ in humans. Magnesium is essential for maintaining normal body and brain functions. Here we show that increasing brain magnesium, using a newly developed magnesium compound (magnesium-L-threonate, $\mathrm{MgT}$ ), prevents cognitive deficits and pathological changes in transgenic mice co-expressing familial ADlinked APP and PS1 variants that mimics the pathological and behavioral changes of human $\mathrm{AD}$ ( $\mathrm{AD}$ mice). In intact mice, brain $\mathrm{Mg}$ content was found to be the lowest among all tissues tested; long-term MgT-treatment significantly elevated Mg levels in brain, and was associated with markedly improved cognitive function. In $\mathrm{AD}$ mice, learning and memory abilities are seriously impaired by 7 months, and completely deteriorate at 15 months. Strikingly, MgT-treatment was effective in preventing such severe learning and memory deterioration during the entire course of AD progression. At the cellular level, MgT-treatment reduced amyloid deposition in hippocampus and frontal cortex, and prevented synapse loss in the dentate gyrus (DG) and CA1 areas. The degree of memory improvement was strongly correlated with the protection of synapse loss, but did not correlate with the reduction of $A \beta$ plaque. Thus, increased brain $\mathrm{Mg}$ might block $\mathrm{A} \beta$-induced synaptic dysfunction. Since AD patients already have $\mathrm{Mg}$ deficiency, increase in brain Mg may represent a new strategy for prevention and amelioration of $\mathrm{AD}$.

Published: 7 February 2012

School of Medicine, Tsinghua University, Beijing, China
doi:10.1186/1750-1326-7-S1-L24

Cite this article as: Liu: Prevention of cognitive deficits in Alzheimer's mouse model by elevating brain magnesium. Molecular

Neurodegeneration 2012 7(Suppl 1):L24.
Submit your next manuscript to BioMed Central and take full advantage of:

- Convenient online submission

- Thorough peer review

- No space constraints or color figure charges

- Immediate publication on acceptance

- Inclusion in PubMed, CAS, Scopus and Google Scholar

- Research which is freely available for redistribution
(C) 2012 Liu; licensee BioMed Central Ltd. This is an Open Access article distributed under the terms of the Creative Commons Attribution License (http://creativecommons.org/licenses/by/2.0), which permits unrestricted use, distribution, and reproduction in any medium, provided the original work is properly cited. 